DOI https://doi.org/10.30525/978-9934-26-110-7-18

\title{
ФУНКЦІОНАЛЬНЕ НАВАНТАЖЕННЯ МЕТАФОР У РОМАНІ КАТРIH ПАНКОЛЬ «UN HOMME À DISTANCE»
}

\author{
Смушак T. В. \\ кандидат філологічних наук, \\ дочент кафедри франиузької філології \\ Прикарпатський національний університет імені Василя Стефаника \\ м. Івано-Франківськ, Україна
}

Одним із прийомів творення змісту художнього твору, який значною мірою впливає на розвиток образного мислення, є метафоризація. Здійснюючи прагматичний вплив на реципієнта, метафори не лише допомагають глибше осмислити якості предметів чи явищ, характери героїв, але й формують поетичну думку, естетичне світобачення. М. Антонівська зазначає: «Метафора $\epsilon$ одним із засобів пізнання реальності, осягнення свідомості, реалізації мовного потенціалу шляхом трансформації сфер доменів: від конкретної до абстрактної, від матеріальної до духовної» [1, с. 115].

Письменник творить метафори базуючись на власному досвіді, власній системі асоціацій, цінностей. Інтерпретуючи роль та функції метафор у художньому творі, краще пізнаємо митця, набуваємо нових знань про його індивідуально-авторський стиль.

Серед авторів, у творчості яких часто домінують метафори, відзначимо сучасну французьку письменницю Катрін Панколь. Метафора $\epsilon$ важливою складовою мовно-змістової структури іï творів, зокрема епістолярного роману «Un homme à distance» (2002р.). Головними героями роману є: Кей Бартольді - продавчиня у книжковому магазині у Фекані (Франція), Джонатан Шилдс - американський письменник. Листуючись із Джонатом, який поштою замовляє книги, Кей виявляе, що вони обоє мають пристрасть до читання літератури, до того ж збігаються їхні читацькі інтереси. Незабаром епістолярні стосунки Кей та Джонатана переростають у справжнє кохання.

Особливістю метафори у романі Катрін Панколь «Un homme à distance» $є$ їі здатність виконувати інформативну функиію. Інформація, що транслюється через призму асоціативних мовних відношень, стає фундаментом для формування уявлень про образи, події, ситуації та ін. В. Харченко наголошує: «Панорамність спирається на зорову природу образу, змушує по-новому поглянути на гностичну суть конкретної 
лексики, конкретних слів, які стають основою, сировиною, фундаментом будь-якої метафори» [3, с. 15]. У літературознавчому словникудовіднику визначено: «Метафора - це перехід інтуїтивного осяяння у сферу раціональних понять» [2, с. 444].

Прикладами інформативної функції метафор у досліджуваному романі можуть слугувати метафори: «On vivait dans notre bulle à trois» [4, c. 136], «Marco s'était fondu en nous» [4, c.136]. Таким чином дізнаємося про минуле життя Кей, про іï щасливе життя 3 коханим чоловіком, про те як вони обоє піклувалися про ії молодшого брата Марка, були справжньою сім'єю. За словами письменниці, разом вони жили немов в одній бульбашці, а Марко неначе розтанув у них.

Не менш значимою у романі «Un homme à distance» $є$ емоиійно-оиінна функція метафори. Зауважимо, що емоційно-оцінну функцію часто відносять до групи прагматичних функцій, що суттєво впливають на внутрішній стан реципієнта. Метафора є відмінним засобом впливу на емоції та почуття адресата, адже образ, закодований у метафорі, викликає у реципієнта певні емоційно-оцінні реакції. Катрін Панколь шляхом творення метафори «Jingle bells, jingle bells sur un mode ricanant, grinçant, une vieille rengaine qui réveille mon cœur rouillé...» [4, с. 37] не лише акцентує на самотності Кей (усі близькі ії покинули), але й викликає у читача співчуття. Уявляючи емоційний стан героїні під час самотнього проживання періоду різдвяних свят, неможливо залишитися байдужим. Розуміємо, що розлука з рідними дуже змінила життя героїні, вона замкнулася в собі, стала відчуженою. В одному з листів вона пише: «Et je me suis construit ma bulle» [4, c. 145].

Вживання метафор у прозі призначене, зокрема, образно відображати дійсність. Метафорі властиво виконувати відображсальну функиію. Проаналізуємо, наприклад, метафору «Vous m'aviez apprivoisée avec vos lettres, avec vos mots, vos formules, vos images, vos narrations» [4, c. 124]. Дана метафора відображає істинне ставлення Кей до переписки із Джонатаном. Героїня стає залежною від їхнього епістолярного спілкування. Вона пише чоловікові про те, що він ії «приручив своїми листами, своїми словами...». Логічним доповненням до вище сказаного стає метафора «Vous remplissiez ma vie, vous y souffliez de l'air chaud, du sirocco, de la tramontane, du mistral, du pampero» [4, с. 124]. Життя Кей справді починає змінюватися. Джонатан «наповнює його, дмухає на нього гарячим повітрям, сироко, трамонтаном, містралем, памперо».

Метафори виконують й характеризувальну функиію. Щоб охарактеризувати пристрасне захоплення Кей художньою літературою, Катрін Панколь конструює метафори: «J'ai dévoré le livre, Jonathan...» 
[4, c. 102], "J'étais partout dans le livre. Dans la terre normande, dans les criques, dans les fuites effrénées sur les falaises, dans la félicité et la douleur» [4, c.103]. В одному зі своїх листів до Джонатана героїня розповідає про прочитання уподобаної книги, яку вона «проковтнула», «була у ній повсюди - у нормандській землі, у бухтах, у постійних втечах на скелі, у блаженстві та у болі».

Шляхом аналізу найбільш виразних метафоричних виразів виокремлюємо, отже, основні функції метафор у романі Катрін Панколь «Un homme à distance», a саме: інформативну, емоційно-оцінну, відображальну, характеризувальну. Створена Катрін Панколь система метафоричних номінацій породжує у реципієнта уяву, яка, у свою чергу, виступає ключем до розуміння даних метафор і передбачає декодування зашифрованої інформації. Асоціації, які постають у процесі сприймання та інтерпретації метафор, дають уявлення про індивідуальний досвід письменниці, іï ставлення до порушених проблем, відображають особливості їі світобачення.

\section{Література:}

1. Антонівська М. О. Лінгвостилістичні особливості функціонування та перекладу метафор у художньому стилі англійської мови. Молодий вчений. 2017. № 8 (48). С. 115-118.

2. Гром'як Р. Літературознавчий словник-довідник / за ред. Р. Гром'яка та ін. Київ : ВЦ «Академія», 2007. 752 с.

3. Харченко В. К. Функции метафоры. Воронеж : Изд-во ВГУ, 1991. $88 \mathrm{c}$.

4. Pancol Katherine. Un homme à distance. Paris : Albin Michel, 2002. $160 \mathrm{p}$. 